\title{
Leder: Forskning på kroppsøving og idrettsfag i skolen
}

Juni 2012 ble den første konferansen "Kroppsøvingsfaget i bevegelse» en realitet. Seksjon for kroppsøving og pedagogikk (ved NIH) med professor Gunn Engelsrud i spissen ønsket å sette forskning på kroppsøving på agendaen gjennom å etablere en årlig konferanse. I 2017 feirer kroppsøvingskonferansen 5 år og vi kan med trygghet si at det er blitt en tradisjon for kroppsøvingsforskere å møtes på NIH juni hvert år, som et ledd $\mathrm{i}$ å bevege forskningsfeltet og faget fremover.

På konferansen i 2015 ble det besluttet å etablere et Nasjonalt nettverk for forskning på kroppsøving og idrettsfag, og i den forbindelse nedsatt et interimsstyre med Professor Gunn Engelsrud som leder. Nettverket ble godkjent på årsmøtet 2016 og nytt styre konstituert bestående av professor Jorunn Spord Borgen (NIH) som leder, samt professor Knut Løndal (HiOA), dosent Bjørg Oddrun Hallås (HVL), førstelektor Egil Galaaen Gjølme (NTNU) og førsteamanuensis Kjersti Mordal Moen (HINN) som medlemmer.

Forskning på skolefagene kroppsøving og idrettsfag har en relativt kort historie i norsk sammenheng. Etablering av den årlige kroppsøvingskonferansen ved NIH har ført til mer engasjement om forskning på kroppsøving og idrettsfag, og ikke minst bidratt til å synliggiøre hva som foregår av forskning på dette feltet i Norge. Det har imidlertid vært diskutert $i$ våre fagkretser at det finnes få nasjonale fagfellevurderte tidsskrift der denne forskningen kan publiseres. På bakgrunn av dette fikk det nyetablerte styret i Nettverk for forskning på kroppsøving og idrettsfag i oppdrag å finne løsninger for mulige publiseringskanaler. Løsningen viste seg å ligge nært, i og med at det nyetablerte tidsskriftet fournal for Research in Arts and Sports Education (JASEd) gierne ville publisere et temanummer fra kroppsøvingskonferansen 2016. Undertegnede ble på bakgrunn av å sitte i styret i Nettverk for forskning på kroppsøving og idrettsfag valgt som gjesteredaktører, og det er med stor glede vi kan ønske deg velkommen som leser av det første temanummeret på kroppsøving og idrettsfag i JASEd.

Det er viktig å merke seg at dette temanummeret omhandler forskning eksplisitt på skolefagene kroppsøving og idrettsfag og på utdanning av kroppsøvingsog idrettsfagslærere. Artikler som faller utenfor forskning på skole - eller lærerutdannings-konteksten har ikke blitt inkludert i dette temanummeret.

Dette temanummeret skal bidra til at vitenskapelige perspektiver på utdanning kan bidra til en tettere kobling mellom fagspesifikk forskning og utdanningsvitenskapelige problemstillinger i skole og lærerutdanning. Mer konkret slik Aasen, Prøitz og Borgen (2005) formulerer det: «Utdanningsvitenskapen kan bidra med innsikt i 


\section{F.S. Borgen og K.M. Moen}

utdanningsrelaterte fenomener og problemer, den kan bidra med kritikk som presiserer eller eventuelt forkaster valgte løsninger, og den kan bidra til å forandre ulike forhold innenfor utdanningsfeltet.» (s. 62).

Innen fristens utløp 15. November 2016 for temanummeret i kroppsøving, hadde vi fått tilsendt 18 artikler. Tre artikler ble ansett som ikke relevant, og det endelige temanummeret består av 6 artikler.

Vår rolle som redaktører har vært å bidra til å utvikle et temanummer med god nivå 1- standard. For å sikre god kvalitet på temanummeret har vi lagt vekt på å ha en tydelig redaksjonell stemme på vegne av fagfeltet. Det har i denne sammenheng også vært viktig å finne fagfeller som er erfarne nok til å gjenkjenne dette nivået og kunne gi konstruktive tilbakemeldinger til forfatterne. For å få til denne typen publisering er vi avhengige av at mange påtar seg fagfelle-oppgaver. Vi vil rette en stor takk til de som har bidratt som fagfeller gjennom denne dugnaden for fagfeltet. Deres bidrag har ført til gode kunnskapsdialoger mellom forfattere, fagfeller og redaktører.

"The publishing game» er krevende. Alle artikler er vurdert gjennom dobbel blind vurdering. Når det har vært sprikende vurderinger ble en tredje fagfelle hentet inn for å få en ekstra vurdering.

En del av artiklene vi mottok viste seg å være basert på bachelor - og masteroppgaver. I utgangspunktet kan en masteroppgave være et godt utgangspunkt for publisering av artikkel. Likevel har vi som redaktører erfart at en god masteroppgave ikke nødvendigvis er publiserbar innenfor et artikkelformat i nivå 1-tidsskrift. Artikkelformatet krever at det er god sammenheng mellom teorigrunnlag, datagrunnlag og analyse. Dette har vært en utfordring for de artiklene vi har fått inn som bygger på masteroppgaver. Det kreves også god faglig modenhet å videreutvikle en masteroppgave til en god artikkel.

Etikk er hjertet $\mathrm{i}$ all forskning. I forbindelse med vårt redaksjonelle arbeid med dette temanummeret har vi i for liten grad støtt på etiske overveielser og drøftinger i de innsendte artiklene. Vi har måttet avvise artikler der forfatterne ikke kan redegjøre for om studien er godkjent av NSD, og at samtykke fra informanter er innhentet. Meldeplikttesten på NSD sine nettsider er ikke tilstrekkelig for å selv avgjøre om prosjektet er meldepliktig. Redaksjonen for tidsskriftet, samt forlaget, har presisert som et krav til artikler at studiene skal være godkjent av NSD som del av kvalitetssikringen.

Dette temanummeret innehar seks artikler. Erik Aasland og Gunn Engelsrud bidrar med artikkelen «Det er lett å se hvem av dere som har god innsats». Om innsats og lererens blikk $i$ kroppsøving. Basert på observasjon fra kroppsøvingsundervisning i videregående skoler i Oslo, undersøker de hvordan innsats konstitueres i kroppsøvingsundervisningen. De analyserer frem hvordan innsats blir noe læreren "lett kan se», og at god innsats oppfattes som at elevene står på slik at de blir drivende svette, at de forbedrer seg, samt at de fremviser positiv innstilling. Denne artikkelen belyser hvordan innsatsforskriften fra 2012 blir forstått og realisert i kroppsøvingsundervisning, og artikkelen er et viktig bidrag til vårt kunnskapsfelt og videre diskusjon om forskriftens plass i faget. 
Kristian Abelsen og Petter-Erik Leirhaug presenterer artikkelen Hva vet vi (ikke) om elevers opplevelser med friluftsliv $i$ norsk skole. En gjennomgang av empiriske studier 1974-2014. De viser at empiriske studier hvor det framkommer kunnskap om elevenes erfaring med friluftsliv i skolen er svært begrenset. De analyserer frem fire tema som blir diskutert nærmere i artikkelen. Disse er læringsutbytte, elevinvolvering, vurdering i friluftsliv og opplevelsene til elever med innvandrerbakgrunn. Denne artikkelen er nyskapende i sin gjennomgang av kunnskapsgrunnlaget innen friluftsliv i skolen.

Kristian Vernegaard, Bjørn Tore Johansen og Tommy Haugen har bidratt med artikkelen Students' motivation in a disc golf-lesson and a soccer-lesson: An experimental study in the Physical Education setting, og har her gjort en sammenlignende studie av elevers motivasjon i en livsstils-inspirert kroppsøvingstime (disc golf) med en tradisjonell kroppsøvingstime (fotball). Selv om studien ikke viser forskjeller mellom de to undervisningstimene når det gjelder motivasjon, viser studien at elevene som hadde disc-golf var mer motivert enn elevene som hadde en tradisjonell kroppsøvingstime. Forfatterne argumenterer for mer variert kroppsøvingsundervisning.

I artikkelen Dans $i$ kroppsøvingsfaget- mer enn gode intensjoner?, undersøker Trond Egil Arnesen, Petter-Erik Leirhaug og Helga Aadland om dans har en styrket posisjon i skolen. Omfanget av danseundervisning i kroppsøvingsfaget sees på som en indikator på operasjonalisert læreplan, og den blir drøftet opp mot dansens posisjon i den formelle læreplan. Forfatterne bruker data fra tre undersøkelser til å danne et bilde av omfanget på hvert trinn i opplæringen. Til nå er det forsket lite på dans i kroppsøving og denne artikkelen bidrar med oppsummerende kunnskap.

I neste artikkel har Hilde Rustad undersøkt dans som del av kroppsøvingslærerutdanningen. Denne artikkelen har tittelen Dans og Kroppsøvingsfaget. Artikkelen undersøker forhold mellom læreres kroppsøvingspraksis, læreplan for kroppsøving i LK06, rammeplan for faglærerutdanningen i kroppsøving og idrettsfag, og studenters erfaringer i kroppsøvingslærerutdanningen for dans som aktivitet. Rustad argumenterer for at læreplan i kroppsøving bør være tydeligere på hva begrepet «dans» skal være i faglærerutdanningen.

Øyvind Førland Standal og Kjersti Moral Moen bidrar med artikkelen Praksis opplering $i$ kroppsøvingslcerar- og idrettsutdanningar: 3 utfordringar for framtidig fagutvikling. Artikkelen oppsummerer resultater fra tre ulike forskningsprosjekter som på ulike vis har undersøkt praksis i kroppsøvings- og idrettsvitenskapelige utdanninger. Disse studiene er basert på litteraturstudie, fokusgruppeintervju og aksjonsforsking. Oppsummert finner Standal og Moen at det er utfordringer i samarbeidet mellom undervisere på høgskolene, praksisveiledere og studenter. På bakgrunn av dette diskuterer de tre utfordringer for praksis i kroppsøvings- og idrettsvitenskapelige utdanninger. Artikkelen belyser relevante problemstillinger i profesjonsutdanninger som har praksis som del av utdanningsløpet. 
Samlet sett er de seks artiklene gode bidrag som beveger forskningen på kroppsøving og idrettsfag fremover. Vi håper de kan være av betydning for debatt, kunnskapsforståelse og inspirasjon til videre forskning.

God lesning!

$$
\text { Forunn Spord Borgen E Kjersti Mordal Moen }
$$

\section{Referanse}

Aasen, P., Prøitz, T. S, \& Borgen, J. S. (2005). Utdanningsvitenskap som forskningsområde. En studie av Vetenskapsrådets støtte til utdanningsvitenskapelig forskning. Vetenskapsrådets rapportserie, Rapport 5/2005. Stockholm: Vetenskapsrådet. 